\title{
KOMUNIKASI NONVERBAL PROKSEMIK DI RUMAH TIDAK LAYAK HUNI
}

\author{
Meria Octavianti* \\ Program Studi Manajemen Komunikasi, Fakultas Ilmu Komunikasi, Universitas Padjadjaran
}

\begin{abstract}
ABSTRAK
Keberadaan ruang dalam sebuah rumah memiliki arti tersendiri bagi para penghuni yang tinggal di dalamnya. Ruang merupakan sebuah pesan nonverbal yang berkontribusi dalam interaksi dan komunikasi. Ruang haruslah memenuhi syarat-syarat tertentu agar dapat memenuhi kebutuhan para penghuninya. Rumah di pemukiman kumuh memiliki ruang-ruang yang berada di bawah standar, salah satunya rumah yang terdapat di Bantaran Sungai Cikapundung Kota Bandung. Rumah yang berdiri hanya pada luas tanah $12 \mathrm{~m}^{2}$ ini harus dihuni oleh delapan anggota keluarga yang terdiri dari tiga buah keluarga inti. Penelitian ini berupaya untuk memberikan gambaran yang komprehensif mengenai komunikasi nonverbal proksemik yang terjadi dalam sebuah rumah yang tidak layak huni. Hasil dari penelitian ini menunjukkan bahwa konsep ruang yang terbentuk dalam sebuah rumah tidak layak huni terbagi menjadi empat kategori yaitu (1) ruang privat untuk setiap penghuni (private space for everyperson), (2) ruang privat untuk keluarga kecil (private space for nuclear family), (3) ruang publik untuk keluarga kecil (public space for nuclear family), dan (4) ruang publik untuk keluarga besar (public space for extended family). Karakteristik ruang di rumah tidak layak huni berkontribusi pada proses komunikasi yang terjadi di antara sesama anggota keluarga. Pesan yang disampaikan dalam proses komunikasi keluarga tersebut hanyalah pesan yang bersifat umum.
\end{abstract}

Kata-kata kunci: Komunikasi nonverbal, proksemik, komunikasi keluarga, rumah tidak layak huni, studi kasus

\section{PROXEMIC NON-VERBAL COMMUNICATION IN A NON STANDARD-FOR-A- LIVING HOUSE}

\begin{abstract}
A space in a house has its own meaning to the member of the house, in which a space itself is a place where every member of the house does their activity. The space, as a non-verbal message, contributes to an intercation and a commmunication that is done by the member of the house. The space has to have certain condition so as to make the member of the house can fulfill their need. Houses in a bellow standard area for a living have bellow standard spaces, for example the houses in Bantaran Sungai Cikapundung Kota Bandung. A house, that is only $12 \mathrm{~m}^{2}$, has to accomodate eight members of the family which consists of three nuclear families. This research tries to give a comprehend description about proxemic non-verbal communication that happens in a non standard-for-a-living house. The result of this research has shown that space concept built in a non standard for-a-living house can be divided into four categories; (1) private space for everyone, (2) private space for nuclear family, (3) public space for nuclear family, and (4) public space for extended family. Characteristics of space in a non standard for-a-living house contribute to the process of communication that occurs between family members. Messages conveyed in the process of family communication are only messages of a general nature.
\end{abstract}

Keywords: Nonverbal communication, proxemic, family communication, non standard-for-a-living house, case study

\footnotetext{
"Korespondensi: Meria Octavianti, S.Sos., M.I.Kom. Program Studi Manajemen Komunikasi, Fakultas Ilmu Komunikasi Universitas Padjadjaran, Jl. Raya Bandung-Sumedang Km.21.Email: octavianti.meria@gmail.com
} 
2008: 18). Keluarga inti merupakan keluarga atau kelompok yang terdiri dari ayah, ibu, dan anak-anak yang belum dewasa atau belum kawin. Sedangan keluarga besar adalah keluarga yang meliputi lebih dari satu generasi dari suatu lingkungan keluarga yang lebih luas daripada ayah, ibu, dan anak-anaknya. Jadi yang dimaksud dengan keluarga inti atau keluarga besar ini bukanlah merujuk pada jumlah atau kuantitas anggota keluarga tersebut, tetapi lebih pada kedekatan dan keeratan hubungan antaranggota keluarga.

Banyak atau tidaknya jumlah anggota keluarga yang tinggal dalam sebuah rumah akan berkontribusi pada jarak atau ruang yang akan terbentuk di antara sesama anggota keluarga. Semakin banyak orang yang tinggal dalam rumah maka akan semakin terbatas ruang pemisah antara penghuni yang satu dengan penghuni yang lain. Begitu pula sebaliknya, semakin sedikit jumlah anggota keluarga, maka jarak atau ruang yang memisahkan para penghuninya akan semakin luas.

Ruang memang tidak dibuat oleh manusia, tetapi manusia-lah yang dapat merasakan keberadaan ruang tersebut. Ruang yang terwujud secara fisik, menurut Suptandar (1999: 93) disebut dengan ruang fisik. Ruang fisik inilah yang merupakan jarak fisik yang terbentuk ketika seseorang berinteraksi dengan orang lain. Ruang fisik inilah yang berkontribusi pada penyampaian pesan komunikasi yang dilakukan oleh seseorang. Antropolog Interkultural Edward T. Hall mengenalkan istilah proksemik, yaitu studi yang mempelajari mengenai penggunaan jarak dalam menyampaikan pesan (Rakhmat, 2003: 83). Hall juga menambahkan bahwa ruang dari sebuah objek serta rancangan interior dapat berkontribusi ke dalam proses komunikasi yang terjadi (Rakhmat, 2003: 291).

Ruang merupakan sebuah bentuk dari pesan nonverbal proksemik. Komunikasi nonverbal sendiri merupakan sebuah bentuk komunikasi lain di luar kata-kata verbal. Komunikasi nonverbal ini memiliki porsi yang lebih besar pada komunikasi antarmanusia dalam kehidupannnya sehari-hari. Albert Mehrabian (dalam Mulyana, 2002: 316) memperikirakan bahwa 93\% dari semua makna sosial dalam komunikasi tatap muka diperoleh melalui syarat-syarat nonverbal. Seperti halnya keberadaan sebuah ruang yang merupakan sebuah bentuk komunikasi nonverbal yang sangat berkontribusi terhadap makna sosial yang terbentuk di antara para penghuni ruang tersebut ketika saling berinteraksi satu sama lain.

Mengkaji keberadaan sebuah ruang terhadap interaksi yang terjadi di antara penghuni ruang tersebut merupakan suatu hal yang menarik. Terlebih lagi apabila ruangan tersebut memiliki karakteristik yang unik atau berbeda dengan ruangan-ruangan lainnya. Seperti halnya salah satu rumah yang terdapat di Bantaran Sungai Cikapundung Tamansari Bandung. Rumah ini bisa dikatakan terdiri dari tiga lantai, tetapi ukuran dari rumah ini sangatlah kecil yaitu luas seluruh bangunan sekityar $34 \mathrm{~m}^{2}$ harus dihuni oleh tiga keluarga yang seluruh anggotanya berjumlah delapan orang. Kondisi seperti ini menyebabkan jarak fisik yang terbentuk di antara anggota keluarga yang tinggal di dalamnya menjadi sangat sempit, hanya terbatas pada jarak intim dan jarak personal. Untuk jarak sosial pun tidak memungkinkan terjadi karena ukuran bangunan dalam setiap lantainya maksimal hanya $3 \mathrm{x}$ 4 meter ditambah lagi dengan banyaknya perbotan rumah tangga yang ada di dalamnya.

Konsep tidak layak huni dibatasi hanya pada penelitian ini karena tingkat kelayakan sebuah rumah itu relatif, tergantung dari sudut pandang mana melihatnya. Pada penelitian ini, rumah dilihat dari konsepsi jarak (proksemik), maka rumah ini dapat dikategorikan sebagai rumah yang tidak layak karena ukuran rumah tidak sesuai dengan jumlah anggota keluarga yang tinggal di dalamnya.

Berdasarkan pemaparan di atas, maka akan dikaji lebih dalam mengenai bagaimana komunikasi nonverbal proksemik yang terbentuk dalam sebuah rumah yang tidak layak huni?. Dari rumusan masalah tersebut, dapat diidentifikasidua masalah penelitian yang lebih khusus yaitu (1) bagaimana konsepsi ruang yang terbentuk dari interaksi antaranggota keluarga yang tinggal di rumah tidak layak huni?, dan (2) bagaimana komunikasi yang terjadi di antara sesama anggota keluarga yang tinggal di rumah 
Permasalahan kemiskinan masyarakat perkotaan juga menjadi dasar dalam penelitian ini. Menurut Asy'ari (1993) problematika sosial di perkotaan memiliki beberapa ciri tertentu yang membedakannya dari problematikaproblematika yang lain. Ciri yang pertama adalah adanya keterbatasan tanah yang timbal balik dengan daya kemampuan warga sehingga menimbulkan harga yang tidak terjangkau oleh rakyat kecil yang berpenghasilan rendah. Hal ini relevan apabila dikaitkan dengan krisis pertanahan di kota akibat peledakan penduduk kota dan urbanisasi. Kedua, tidak adanya sinkronisasi antara pendapatan rakyat per kapita dengan kemampuan beli atau sewa dan perbaikan rumah.Kenyataan demikian dikarenakan kebanyakan warga perkotaan yang rata-rata hidup di bawah standar karena mereka adalah para pekerja atau pendatang dari pedesaan yang tidak memiliki kemampuan atau profesionalisme. Ketiga, terbatasnya kemampuan pemerintah dalam hal dana pembangunan perumahan. Keempat, munculnya industrialisasi dan membanjirnya urbanisasi, mengakibatkan kepadatan penduduk yang sangat cepat dan sulit untuk dikendalikan.

Menurut Oscar Lewis (dalam Suparlan, 1993: 5-11), salah satu ciri dari kemiskinan di daerah perkotaan atau pada tingkat lokal dicirikan oleh kondisi rumah-rumah bobrok, penuh sesak, bergerombol. Rumah yang tidak layak huni di bantaran Sungai Cikapundung ini merupakan salah satu bukti dari apa yang diungkapkan oleh teori kemiskinan perkotaan.

Komunikasi keluarga yang terbentuk di dalam rumah yang tidak layak huni akan berbeda dengan komunikasi keluarga yang terbentuk di rumah yang layak huni. Keluarga merupakan hasil dari sebuah interaksi. Hubungan perkawinan, darah, maupun adopsi itu muncul dari adanya interaksi dari anggotaanggota di dalamnya. Maka dari itu keluarga memiliki sistem jaringan interaksi yang lebih bersifat interpersonal. Dimana setiap anggota dalam keluarga dimungkinkan untuk mempunyai intensitas hubungan antara satu sama lain, baik di antara antara ayah dan ibu, ayah dan anak, ibu dan anak, maupun antara anak dan anak (Khairuddin, 2008: 5).

Terdapat dua jenis keluarga yaitu keluarga inti (nuclear family) dan keluarga besar (extended family). Keluarga inti (nuclear family) adalah keluarga yang terdiri dari ayah, ibu, dan anak-anaknya yang belum dewasa atau belum kawin. Sedangkan keluarga luas atau extended family adalah satuan keluarga yang meliputi lebih dari satu generasi dari suatu lingkungan keluarga yang lebih luas daripada hanya ayah, ibu, dan anak-anaknya. (Khairuddin, 2008: 19). Untuk memperjelas perbedaan kedua jenis keluarga ini, dapat dilihat dari ilustrasi di bawah ini:

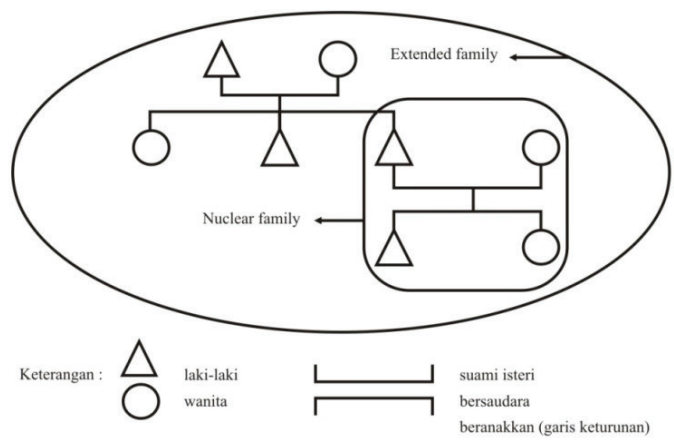

Gambar 1. Nuclear \& Extended Family

Sumber: Khairuddin. 2008. Sosiologi Keluarga. Yogyakarta: Liberty. hal. 19

Penelitian ini akan fokus pada komunikasi nonverbal proksemik yang terjadi di rumah yang tidak layak huni. Komunikasi nonverbal adalah bentuk komunikasi lain di luar katakata. Komunikasi nonverbal memiliki porsi yang besar dalam komunikasi antarmanusia dalam kehidupan sehari-hari. Seperti yang diungkapkan oleh Birdwhistell (dalam Rakhmat, 2003: 288) bahwa jika dibandingkan dengan komunikasi verbal, tidak lebih dari $30 \%$ sampai $35 \%$ makna sosial percakapan atau interaksi dilakukan dengan kata-kata, selebihnya komunikasi dilakukan melalui komunikasi nonverbal. Selain itu, Albert Mehrabian memperkirakan 93\% dari semua makna sosial dalam komunikasi tatap muka diperoleh melalui syarat-syarat nonverbal (Mulyana, 2002: 316).

Mulyana (2002:317) menjelaskan beberapa pesan nonverbal yang dapat dikategorikan sebagai pesan nonverbal yang penting, mulai dari pesan nonverbal yang bersifat perilaku hingga pesan nonverbal yang terdapat dalam lingkungan. Berikut merupakan pesan nonverbal tersebut: (1) bahasa tubuh yang terdiri dari isyarat tangan, gerakan kepala, postur tubuh dan posisi kaki, ekspresi wajah dan tatapan mata, (2) sentuhan, atau yang lebih dikenal dengan 
dan fase jauh (0,75-1,20 m), (3) jarak sosial, yaitu jarak antarindividu yang terdiri dari fase dekat (1.20-2,10 m) dan fase jauh $(2,10$ 3,60 m). Jarak antarindividu ini merupakan batas normal bagi individu dengan kegiatan serupa atau kelompok sosial yang sama.Pada kenyataannya, jarak ini merupakan patokan dasar dalam pembentukkan ruang atau dalam perencanaan ruang, (4) jarak publik, yaitu jarak antarindividu yang terdiri dari fase dekat $(3,60-7,50 \mathrm{~m})$ dan fase jauh $(>7,50$ $\mathrm{m})$. Jarak antarindividu ini memungkinkan seseorang untuk membina hubungan yang lebih formal.

Ruang personal akan berkaitan dengan teritori dan teritorialitas. Teritori memiliki artian sebagai wilayah atau daerah sedangkan teritorialitas adalah wilayah yang dianggap sudah menjadi hak seseorang. Misalnya di dalam sebuah rumah, kamar tidur merupakan wilayah yang sudah dianggap menjadi hak bagi yang menggunakannya. Meskipun orang yang bersangkutan sedang tidak tidur di sana dan ada seseorang yang memasuki kamar tersebut tanpa izinnya, maka ia akan tersinggung.

Sebagai media komunikasi, teritori terbagai ke dalam beberapa golongan. Klasifikasi teritori yang banyak digunakan adalah klasifikasi yang dibuat oleh Altman (dalam Laurens, 2005: 126). Berikut merupakan klasifikasi teritori tersebut: (1) teritori primer. Teritori primer adalah tempat-tempat yang sangat pribadi sifatnya, hanya boleh dimasuki oleh orang-orang yang sudah sangat akrab atau yang sudah mendapatkan izin khusus. Teritori ini dimiliki oleh perseorangan atau sekelompok orang yang juga mengendalikan penggunaan teritori tersebut secara relatif tetap, (2) teritori sekunder. Teritori sekunder adalah tempattempat yang dimiliki bersama oleh sejumlah orang yang sudah cukup saling mengenal. Kendali pada teritori ini tidaklah sepenting teritori primer dan kadang berganti pemakai, atau berbagi pnggunaan dengan orang asing, (3) teritori publik. Teritori publik adalah tempat-tempat yang terbuka untuk umum.
Pada prinsipnya, setiap orang diperkenankan untuk berada di tempat tersebut.

Dalam sebuah teritori juga terdapat pembagian ruang yaitu ruang publik, ruang privat dan ruang peralihan. Ruang publik adalah area yang terbuka. Ruang ini dapat dicapai oleh siapa saja pada waktu kapan saja dan tanggung jawab pemeliharaannya adalah kolektif. Ruang privat adalah area yang aksesibilitasnya ditentukan oleh seseorang atau sekelompok orang dengan tanggung jawab ada pada mereka. Sementara itu, ruang peralihan adalah area yang dibuat sebagai penghubung berbagai teritori yang berbeda sifatnya (Laurens, 2005: 143).

Selain konsep teritori, konsep privasi perlu untuk dipahami dan dimengerti untuk dapat mengetahu gambaran yang komprehensif mengenai komuniaksi nonverbal proksemik di rumah yang tidak layak huni. Privasi adalah keinginan atau kecenderungan dalam diri seseorang untuk tidak diganggu kesendiriannya. Dalam ilmu psikoanalisis, privasi berarti dorongan untuk melindungi ego seseorang dari gangguan yang tidak dikehendakinya (Laurens, 2005: 157).

Privasimerupakan suatu proses yang sangat penting dalam hidup manusia. Untuk mampu mendapatkan privasi, seseorang harus terampil membuat keseimbangan antara keinginannya dengan keinginan orang lain dan lingkungan fisik di sekitarnya.Amos (1977) mengemukakan bahwa privasi adalah kemampuan seseorang atau sekelompok orang untuk mengendalikan interaksi mereka dengan orang lain, baik secara visual maupun audial untuk mendapatkan apa yang diinginkannya. Pengertian-pengertian di atas menunjukkan adanya kontrol selektif dan tidak serba otomatis dalam konsep privasi. Hal ini berarti privasi tidak menutup semua jalur menuju diri seseorang, tetapi mampu mengontrol terbuka atau tertutupnya suatu jalur komunikasi (Laurens, 2002: 160).

Berdasarkan pemaparan tersebut, maka dapat dibuat sebuah bagan kerangka pemikiran seperti di bawah ini: 


\section{PENDAHULUAN}

"We can not not communicate", ungkapan yang disampaikan oleh Harold Lasswell ini menunjukkan bahwa setiap insan manusia tidak mungkin bisa terlepas dari komunikasi. Sejak pertama kalinya dilahirkan ke bumi ini, seorang bayi akan langsung berkomunikasi dengan tangisannya. Kemudian dia juga tersenyum untuk menunjukkan kebahagiannya. Walaupun bayi belum bisa berbicara secara verbal, tetapi bayi berkomunikasi dengan menggunakan isyarat nonverbal. Bayi berinteraksi dengan anggota keluarganya untuk belajar segala hal, mulai dari mengenal kata, kalimat sampai akhirnya dia pun bisa berbicara. Itu merupakan salah satu contoh kecil peristiwa komunikasi yang terjadi di antara sesama anggota keluarga. Komunikasi yang terjadi di antara sesama anggota keluarga tersebut dikenal dengan komunikasi keluarga.

Keluarga menurut Elliot dan Merrill merupakan "... a group of two or more persons residing together who are related by blood, marriage, or adoption..." (dalam Khairuddin, 2008:3). Keluarga pada dasarnya merupakan suatu kelompok yang terbentuk dari suatu hubungan perkawinan, darah, maupun adopsi. Hubungan tersebut muncul dari adanya interaksi antar anggota-anggota yang tinggal di dalamnya, sehingga dapat dikatakan bahwa keluarga merupakan hasil dari sebuah interaksi. Galvin dan Brommel (1982: 2) menambahkan bahwa interaksi antaranggota keluarga terjadi karena adanya komunikasi. Sehingga dapat dipastikan bahwa untuk dapat memahami konsep komunikasi keluarga dengan baik, diperlukan pengetahuan mengenai interaksi yang terjadi di antara anggota-anggota keluarga tersebut.

Rumah merupakan tempat terjadinya interaksi antaranggota keluarga. Di dalam sebuah rumah, seorang ibu dan ayah dapat berhubungan intim untuk memperoleh keturunan. Di dalam rumah pula, seorang anak dididik dan dibesarkan oleh orang tuanya. Kehadiran sebuah rumah memiliki arti penting bagi kelangsungan hidup sebuah keluarga. Guharja (1992: 9-10) menyatakan bahwa sebuah keluarga itu harus memenuhi kebutuhan pangan, papan, sandang, dan kesehatan untuk pengembangan fisik dan sosial para anggota keluarganya. Keberadaan sebuah rumah menjadi salah satu syarat penting yang harus ada dalam sebuah keluarga. Hal tersebut diperkuat oleh Burgess dan Locke (1960: 70) yang menyatakan bahwa salah satu ciri keluarga adalah anggota-anggotanya hidup bersama di bawah satu atap dan merupakan satu susunan satu rumah tangga.

Oleh karena itu, setiap keluarga pastilah tinggal dalam sebuah rumah, baik itu rumah hak milik ataupun tidak, rumah besar ataupun rumah yang kecil, layak atau pun tidak layak. Kondisi fisik sebuah rumah memiliki kontribusi yang cukup besar pada interaksi yang terjadi di antara para penghuninya. Perbedaan bentuk atau desain rumah akan berpengaruh pada siapa akan berinteraksi dengan siapa, di mana, kapan dan berapa lama interaksi tersebut dilakukan serta pesan-pesan apa saja yang dibicarakan saat anggota keluarga berinteraksi dengan anggota keluarga lainnya di dalam rumah tersebut (Galvin dan Brommel, 1982: 251-252).

Bentuk dan desain rumah juga akan berpengaruh pada pembagian wilayah (territory) dan privasi dari setiap anggota keluarga serta berpengaruh pula pada tingkat kemudahan bagi setiap anggota keluarga untuk bisa berkumpul bersama-sama (Galvin dan Brommel, 260). Seperti yang dikemukakan oleh Stanford Lyman dan Marvin Scott (2004: 57) dan Mulyana (2002: 358) bahwa wilayah rumah (home territory) adalah wilayah yang bebas dimasuki dan digunakan oleh orang yang mengakui memilikinya. Dimana orangorang di dalamnya akan mendapatkan privasi yang lebih besar karena orang asing akan jarang mengusik ruang yang mereka anggap bukan milik mereka (rumah mereka).

Berbicara mengenai jumlah anggota keluarga yang tinggal dalam sebuah rumah, dapat dijumpai keluarga variasi yang beragam. Sepasang suami istri yang terikat perkawinan, sudah dapat dikatakan sebagai sebuah keluarga walaupun mereka belummempunyai keturunan. Begitu pula dengan keluarga yang terdiri dari pasangan suami istri yang sudah dikaruniai banyak anak. Jadi, konsep keluarga tidak bisa hanya dibatasi oleh jumlah atau kuantitas dari jumlah anggota keluarga tersebut.

Dalam konsep keluarga, dikenal istilah nuclear family atau keluarga inti dan juga extended family atau keluarga besar(Khairuddin, 
tidak layak huni dilihat dari aspek nonverbal proksemik?.

Tujuan dilakukannya penelitian mengenai komunikasi nonverbal proksemik di rumah tidak layak huni ini adalah untuk memperoleh gambaran yang komprehensif mengenai komunikasi nonverbal proksemik yang terbentuk dalam sebuah rumah yang tidak layak huni, seperti (1) konsepsi ruang yang terbentuk dari interaksi antaranggota keluarga yang tinggal di rumah tidak layak huni, dan (2) komunikasi yang terjadi di antara sesama anggota keluarga yang tinggal di rumah tidak layak huni dilihat dari aspek nonverbal proksemik.

Secara akademis, penelitian ini diharapkan memberikan kontribusi bagi perkembangan kajian ilmu komunikasi, khusunya dalam kajian komunikasi nonverbal proksemik dalam sebuah rumah yang tidak layak huni. Sedangkan secara praktis penelitian ini dapat berkontribusi dan bermanfaat bagi beberapa kalangan, diantaranya adalah memberikan kontribusi dalam penyusunan program penyuluhan komunikasi, dengan sasaran keluarga-keluarga yang tinggal di lingkungan kumuh serta memberikan referensi bagi peneliti-peneliti berikutnya, terutama yang akan memilih tema, perspektif, atau wilayah penelitian yang serupa.

Teori interaksi simbolik menjadi dasar dalam penelitian mengenai komunikasi nonverbal di rumah tidak layak huni. Teori ini memandang aktivitas manusia sebagai suatu aktivitas yang khas berupa komunikasi dengan menggunakan simbol. Berdasarkan teori interaksi simbolik, individu itu bersifat aktif, reflektif, dan kreatif, menafsirkan, menampilkan perilaku yang rumit dan sulit diramalkan. Paham Interaksi Simbolik menolak gagasan bahwa individu adalah organisme pasif yang perilakunya ditentukan oleh kekuatankekuatan atau struktur yang ada di luar dirinya. Oleh karena individu terus berubah, maka masyarakatkan pun berubah melalui interaksi. Jadi interaksi yang dianggap variabel penting yang menentukan perilaku manusia, bukan struktur masyarakat. Struktur itu sendiri tercipta dan berubah karena interaksi manusia, yakni ketika individu-individu berpikir dan bertindak secara stabil terhadap seperangkat objek yang sama (Mulyana, 2002: 61).

Teori interaksi simbolik menyatakan bahwa kehidupan sosial pada dasarnya adalah interaksi manusia dengan menggunakan simbol-simbol. Menurut Deddy Mulyana (2002: 71) premis-premis interaksi simbolik adalah (1) individu merespons suatu situasi simbolik. Mereka merespon lingkungan, termasuk objek fisik (benda) dan objek sosial (perilaku manusia) berdasarkan makna yang dikandung komponen-komponen lingkungan tersebut bagi mereka, (2) makna adalah produk interaksi sosial, karena itu makna tidak melekat pada objek, melainkan dinegosiasikan melalui penggunaan bahasa, (3) makna yang diinterpretasikan individu dapat berubah dari waktu ke waktu, sejalan dengan perubahan situasi yang ditemukan dalam interaksi sosial. Perubahan interpretasi dimungkinkan karena individu dapat melakukan proses mental, yakni berkomunikasi dengan dirinya sendiri.

Konsep-konsep teoretik dari interaksi simbolik dapat digunakan untuk menganalisis realitas komunikasi antaranggota keluarga. Dimana mereka memahami simbol-simbol dan menentukan sikap berdasarkan pemaknaannya. Bagaimana mereka menggunakan simbol, menukarkannya, dan memahaminya saat berinteraksi dengan sesama anggota keluarga. Lewat teori interaksi simbolik, dapat dijelaskan bagaimana setiap anggota keluarga memandang dirinya sendiri dan anggota keluarga lainnya saat saling berinteraksi di dalam sebuah rumah.

Rumah, dalam hal ini berarti ruangan tempat tinggal, bukan hanya sekedar fakta fisik saja. Rumah juga bisa memiliki arti simbolik tertentu ketika ruangan rumah tersebut diinteraksikan dengan pelaku-pelaku yang berada di dalamnya. Penataan ruangan tempat tinggal bisa menimbulkan penafsiran subjek, dalam hal ini berarti para anggota keluarga yang tinggal di dalamnya. Bagaimana simbolsimbol yang dimunculkan dalam penataan ruangan tempat tinggal akan berpengaruh pada perilaku setiap anggota keluarganya. Oleh karena itu, penelitian ini menggunakan teori interaksi simbolik sebagai dasar pijakan berpikir, karena pada dasarnya perilaku setiap anggota keluarga itu merupakan hasil interaksi terhadap simbol-simbol. Simbol-simbol merupakan produk interaksi sosial, jadi sebuah makna itu tidak melekat pada sebuah objek melainkan dinegosiasikan melalui penggunaan bahasa. 
sebutan haptika (haptics) yaitu studi tentang sentuh menyentuh, (3) parabahasa yaitu pesan nonverbal yang merujuk pada aspek-aspek suara selain ucapan yang dapat dipahami, misalnya kecepatan berbicara, nada (tinggi atau rendah), intensitas (volume) suara, intonasi, dialek, suara terputus-putus, suara yang gemetar, suitan, siulan, tawa, erangan, tangisan, gerutuan, gumaman, desahan, dan sebagainya, (4) penampilan fisik, baik itu busana dan aksesoris yang digunakan, serta karakteristik fisik seseorang seperti bentuk tubuh, warna kulit, model rambut, dan sebagainya, (5) bau-bauan, (6) orientasi ruang dan jarak pribadi, (7) konsep waktu, (8) warna, (9) artefak atau benda apa saja yang dihasilkan oleh kecerdasan manusia, yang digunakan untuk memenuhi kebutuhan hidup manusia dan dalam interaksi manusia, sering mengandung makna-makna tertentu.

Komunikasi nonverbal proksemik menjadi fokus dalam penelitian ini. Komunikasi nonverbal proksemik merupakan studi yang mempelajari tentang penggunaan jarak dalam menyampaikan pesan. Istilah ini pertama dikenalkan oleh antropolog interkultural, Edward T. Hall (Rakhmat, 2003: 83). Konsep proksemik yang diungkapkan oleh Edward T. Hall menelaah persepsi manusia atas ruang (pribadi dan sosial), cara manusia menggunakan ruang dan pengaruh ruang terhadap komunikasi (Mulyana, 2002: 356).

Stanford Lyman dan Marvin Scott membagi wilayah interaksi antar sesama manusia ke dalam empat kategori (Mulyana, 2002: 358). Berikut merupakan keempat kategori tersebut: (1) Wilayah Publik (public territory). Wilayah publik adalah tempat yang secara bebas dimasuki dan ditinggalkan orang, dengan sedikit pengecualian (hanya boleh dimasuki oleh kalangan tertentu atau dengan syarat tertentu). Beberapa contoh yang masuk ke dalam wilayah publik adalah jalan raya, tempat berbelanja, taman kota, (2) Wilayah Interaksional (Interactional Territory). Wilayah Interaksional adalah wilayah yang menjadi tempat pertemuan dan memungkinkan semua orang berkomunikasim secara informal.Contoh wilayah yang masuk ke dalam kategori wilayah interkasional adalah tempat pesta, tempat cukur, (3) Wilayah Rumah (Home Territory). Wilayah rumah maksudnya adalah wilayah publik yang bebas dimasuki dan digunakan oleh orang yang mengakui memilikinya. Di mana orang-orang di dalamnya akan mendapatkan privasi yang lebih besar karena orang asing akan jarang mengusik ruang yang mereka anggap bukan milik mereka (rumah mereka). Contohnya adalah rumah tempat tinggal, bar homoseks, klub privat, (4) Wilayah Tubuh (Body Territory). Wilayah tubuh ini adalah wilayah yang masuk ke dalam wilayah pribadi seseorang. Di mana wilayah ini akan selaluu dibawa oleh setiap orang ke mana pun dia pergi, baik secara disadari ataupun tidak disadari. Wilayah atau ruang pribadi ini bersifat imajiner, di mana bila terjadi pelanggaran akan menimbulkan ketidaknyaman bagi orang tersebut.

Pada penelitian kali ini lebih banyak dibahas mengenai wilayah rumah (home territory) dan wilayah tubuh (body territory). Kedua pokok bahasan tersebut akan memiliki lebih banyak penekanan karena yang menjadi objek dalam penelitian kali ini adalah dimensi ruang dalam sebuah rumah tidak layak huni dan subjek penelitiannya adalah semua orang yang tinggal dalam rumah tersebut.

Selain itu, ruang personal merupakan konsep yang penting yang harus dipahami dalam penelitian ini. Menurut Robert Sommer (dalam Laurens, 2005: 108), ruang personal sebagai suatu area dengan batas maya yang mengelilingi diri seseorang di mana orang lain tidak diperkenankan masuk ke dalamnya. Jadi ruang personal itu seolah-oleh seperti sebuah balon atau tabung yang menyelubungi seseorang, yang membatasi dirinya dengan orang lain dan juga bisa membesar atau mengecil tergantung pada siapa yang berada dihadapannya.

Edward T. Hall (1963) berpendapat bahwa ruang personal adalah suatu jarak komunikasi, di mana jarak antarindividu ini juga merupakan jarak berkomunikasi (Laurens, 2002: 112). Hall membagi jarak antarindividu ini dalam empat jenis, yaitu: (1) jarak intim, yaitu jarak antarindividu yang terdiri dari fase dekat $(0,00-0,15 \mathrm{~m})$ dan fase jauh $(0,15-0,50 \mathrm{~m})$. Pada jarak ini tidak diperlukan usaha keras seperti berteriak atau menggunakan gerak tubuh untuk berkomunikasi, cukup dengan berbisik, (2) jarak personal, yaitu jarak antarindividu yang terdiri dari fase dekat $(0,50-0,75 \mathrm{~m})$ 


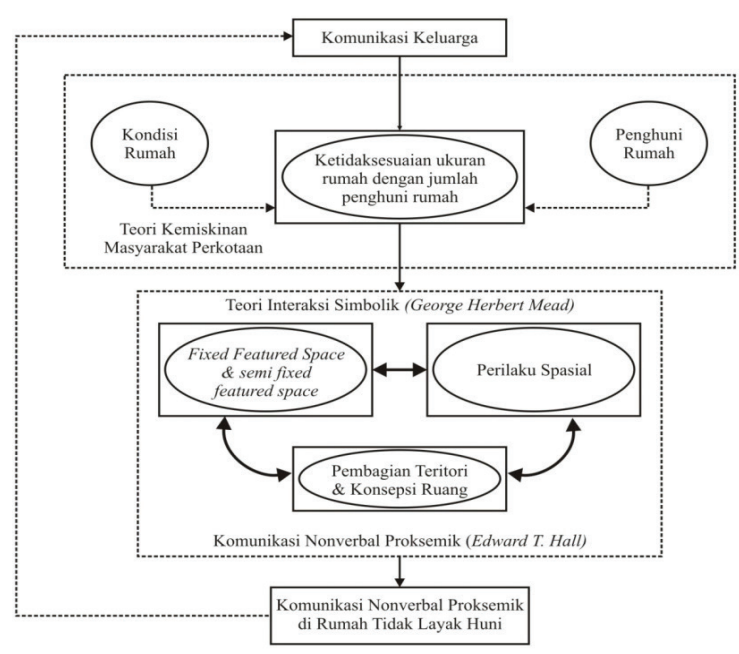

Bagan 1. Kerangka Pemikiran

\section{METODE PENELITIAN}

Berdasarkan masalah dan tujuan penelitian, maka penelitian ini dilakukan dengan menggunakan metode penelitian kualitatif. Pendekatan studi kasus merupakan pendekatan yang paling pas untuk mengungkap fenomena komunikasi nonverbal di rumah tidak layak huni karena dengan menggunakan pendekatan ini maka peneliti dapat mempelajari semaksimal mungkin setiap ruang yang ada dalam rumah tersebut dan kontribusinya terhadapinteraksi dan komunikasi di antara sesama penghuni rumah. Selain itu, dengan pendekatan ini peneliti juga memberikan pandangan yang komprehensif dan mendalam mengenai subjek yang diteliti, yaitu sekelompok orang yang termasuk dalam sebuah keluarga besar (extended family) dan tinggal di sebuah rumah yang tidak layak huni.

Stake 1995 dalam Creswell (1998: 62) menyatakan bahwa fokus dari penelitian studi kasus adalah suatu kasus yang spesifik dan unik. Keunikan kasus berkaitan dengan hakikat kasus tersebut, latar belakang historis, latar fisik, konteks kasus (khususnya ekonomi, politik, hukum, dan estetika) serta kasus-kasus lain di sekitar yang dipelajari oleh informan mengenai kasus tersebut (Salim, 2001: 97). Peneliti mengangkat fenomena ini sebagai bahan kajian penelitian dikarenakan peneliti melihat adanya keunikan di dalamnya. Peneliti merasa terdorong untuk mengetahui secara lebih jauh dan lebih dalam mengenai fenomena kehidupan keluarga yang tinggal di pemukiman kumuh. Terlebih lagi, ketertarikan peneliti semakin meningkat ketika melihat ada sebuah rumah di kawasan kumuh Pulosari, yang sangat tidak layak menjadi sebuah tempat tinggal tetapi dihuni oleh banyak anggota keluarga.

Rumah ini dapat dikategorikan sebagai rumah yang tidak layak huni karena rumah ini hanya memiliki luas tanah $12 \mathrm{~m}^{2}$ dan luas bangunan $34 \mathrm{~m}^{2}$, sedangkan menurut Standar Nasional Indonesia (SNI), yang disampaikan oleh Probo Hindarto (dalam Konsep Rumah dan Interior Rumah), kebutuhan ruang untuk satu orang penghuni rumah saja adalah sebesar $9 \mathrm{~m}^{2}$, dengan ambang batas 7,2 $\mathrm{m}^{2}$. Jadi misalnya sebuah rumah direncanakan dihuni oleh 4 orang, maka sebaiknya luas rumah tidak kurang dari $36 \mathrm{~m}^{2}$. Meskipun demikian, kita tahu bahwa luas rumah tinggal $36 \mathrm{~m}^{2}$ sudah cukup sempit untuk dihuni 4 orang.

Jumlah penghuni yang tinggal dalam rumah ini adalah sebanyak 8 orang dengan luas tanah hanya $12 \mathrm{~m}^{2}$ dan luas bangunan seluruhnya adalah $34 \mathrm{~m}^{2}$. Berdasarkan pada ukuran luas bangunan dan jumlah penghuni dalam rumah tersebut, maka rumah ini dapat diklasifikasikan kepada sebuah rumah yang tidak layak huni. Hal tersebut dikarenakan apabila menyesuaikan dengan Standar Nasional Indonesia (SNI), rumah ini seharusnya memiliki luas bangunan adalah sebesar $72 \mathrm{~m}^{2}$ atau minimal $57,6 \mathrm{~m}^{2}$.

Paparan di atas merupakan suatu indikator bahwa kondisi ini merupakan sebuah kasus yang unik yang terdapat dalam sebuah sistem sosial. Seperti yang disampaikan (2013: 188) bahwa studi kasus adalah dapat berupa sebuah ekplorasi dari sebuah kasus tertentu yang melibatkan berbagai sumber informasi yang kaya dalam suatu konteks. Kasus juga dapat dikaji bukan hanya oleh suatu program atau peristiwa tetapi juga oleh suatu individu (Creswell dalam Riantie, 2013: 199). Daam penelitian ini, kasus dari keberadaan sebuah rumah tidak layak huni akan dikaji melalui interaksi dan komunikasi yang terjadi di antara anggota keluarga (individu) yang tinggal di dalam rumah tersebut.

Penelitian ini khusus dilakukan pada sebuah rumah yang sangat tidak memenuhi standar kelayakan, baik dari segi ukuran maupun desain rumah. Rumah tersebut dihuni oleh tiga keluarga yang terdiri dari delapan orang. Oleh karena itu yang menjadi 
subjek penelitian ini adalah seluruh anggota keluarga yang tinggal di rumah tersebut, yang terdiri dari 3 nuclear family dengan jumlah anggota extended family sebanyak 8 orang.

Teknik pengumpulan data yang dilakukan dalam penelitian ini adalah dengan observasi partisipatif (participant observation), wawancara mendalam (in-depth interview), dan melakukan analisis dokumen (document analysis). Hasil akhir dari penelitian ini adalah sebuah konsepsi ruang yang khusus terbentuk di rumah yang tidak layak huni dan sebuah model mengenai komunikasi nonverbal proksemik yang terbentuk di rumah yang tidak layak huni.

\section{HASIL DAN PEMBAHASAN}

Proksemik merupakan studi yang mempelajari tentang penggunaan jarak dalam menyampaikan pesan. Istilah yang pertama kali dikenalkan oleh antropolog interkultural, Edward T. Hall. Dalam studi mengenai proksemik ini, Hall juga menyatakan bahwa pengaturan jarak, ruangan objek dan rancangan interior dapat berkontribusi ke dalam proses komunikasi yang terjadi (Rakhmat, 2003: 291).

Untuk dapat memperoleh gambaran yang komprehensif mengenai komunikasi nonverbal proksemik di rumah yang tidak layak huni, tidak cukup hanya dengan mengetahui penggunaan setiap ruangan yang ada di dalam rumah tersebut, tetapi perlu diketahui juga interaksi yang terjadi di antara sesama pengguna ruangan. Interaksi tersebut antara lain dengan siapa biasanya penghuni rumah menggunakan ruangan tersebut, melakukan apa, berapa lama, dan peristiwa komunikasi apa saja yang terjadi saat interaksi tersebut berlangsung.

Penelitian menunjukkan bahwa konsepsi ruang di rumah tidak layak huni dapat dibagi menjadi empat ruang yaitu private space for everyperson (ruang privat untuk setiap anggota keluarga), private space for nuclear family (ruang privat untuk keluarga inti), public space for nuclear family (ruang publik untuk keluarga inti),dan public space for extended family (ruang publik untuk keluarga besar). Keempat konsepsi ruang ini akan sangat berhubungan dengan pembagian teritori (wilayah) yang dikemukakan oleh Altman (dalam Laurens, 2005: 126) Apakah konsepsi ruang tersebut masuk ke dalam kategori teritori primer, teritori sekunder, dan teritori publik atau tidak termasuk ke dalam ketiga bentuk teritori tersebut.

Ruang Privat bagi Setiap Anggota Keluarga di Rumah Tidak Layak Huni. Ruang privat merupakan sebuah wilayah yang aksesibilitasnya ditentukan oleh seseorang atau sekelompok orang dengan tanggung jawab ada pada mereka. Orang lain yang tidak memiliki hak atas ruangan tersebut tidak mudah untuk bisa memasuki ruang tersebut, melainkan harus memperoleh izin dari pihak yang memiliki hak atas ruang tersebut. Kamar mandi di rumah tidak layak huni ini merupakan salah satu ruangan di rumah tidak layak huni yang masuk ke dalam kategori ruang privat.

Perilaku spasial yang terjadi di kamar mandi bersifat privat, yaitu hanya dilakukan seorang diri oleh setiap penghuni rumah. Di dalam rumah ini, kamar mandi merupakan satu-satunya ruangan yang dilengkapi dengan fasilitas pintu yang bisa dikunci dari dalam. Jadi saat penghuni rumah menggunakan ruangan ini, dia dapat memperoleh privasi yang sangat besar di ruangan ini. Tidak ada seorang pun yang bisa mengganggunya karena ruangan ini berada dalam posisi yang terkunci dari dalam. Hanya penghuni rumah yang sedang menggunakan ruangan ini yang dapat membuka pintu yang menjadi akses bagi terbentuknya sebuah interaksi yang lain. Ruangan ini adalah satu-satunya ruangan yang memungkinkan setiap penghuni rumah untuk dapat melakukan hal-hal yang bersifat pribadi untuk dirinya sendiri.

Berdasar pada kondisi yang sudah dijabarkan di atas maka ruangan kamar mandi ini dapat disebut sebagai private space for everyperson atau ruangan privat untuk setiap anggota keluarga yang tinggal di rumah tidak layak huni. Everyperson di sini berarti setiap individu yang merupakan anggota keluarga yang tinggal di rumah tidak layak huni, sebagai diri pribadi mereka sendiri.

Kamar mandi, sebagai sebuah private space for everyperson, merupakan satu-satunya ruangan di rumah tidak layak huni yang termasuk ke dalam kategori teritori sekunder. 
Hal tersebut dikarenakan kepemilikan atau penggunaan kamar mandi ini bergantian. Seluruh anggota keluarga yang tinggal di rumah tidak layak huni memiliki ruangan ini. Dalam penggunaannya, ruangan ini tidak bisa digunakan bersama-sama, tetapi harus bergantian sesuai dengan kesepakatan yang sudah ada sebelumnya, pengecualian untuk informan yang masih balita. Hal tersebut sesuai dengan apa yang disampaikan oleh Laurens (2005: 127) bahwa teritori sekunder sendiri merupakan tempat-tempat yang dimiliki bersama oleh sejumlah orang yang sudah cukup saling mengenal. Kendali pada teritori ini tidaklah sepenting teritori primer dan kadang berganti pemakai atau berbagi penggunaan dengan orang asing.

Di dalam private space for everyperson ini, setiap penghuni rumah bebas untuk dapat mengakses ruangan dan memperoleh privasi ketika menggunakan ruangan ini. Walaupun begitu derajat aksesibiltas dalam sebuah konsep privasi itu merupakan suatu peraturan atau ketentuan (Laurens, 2005: 140). Penggunaan kamar mandi oleh para anggota keluarga yang tinggal di rumah tidak layak huni, sudah menjadi sebuah peraturan atau ketentuan yang sudah disepakati bersama oleh seluruh penghuni rumah. Kesepakatan tidak dilakukan secara khusus, tetapi kesepakatan tersebut muncul seiring dengan berjalannya waktu.

Kendali yang terjadi di dalam ruangan ini tidak sepenting kendali yang ada di teritori primer. Dalam teritori primer, pemiliknya dapat dengan tegas menentukan siapa yang boleh dan siapa yang tidak boleh masuk ke dalam teritorinya tersebut. Tetapi untuk kamar mandi, yang memiliki fungsi umum, tidak ada kendali yang sebesar itu. Kendali di sini hanyalah terjadi ketika seorang penghuni rumah sedang menggunakan ruangan ini sesuai dengan kesepakatan dengan anggota keluarga lainnya.

Ruang Privat bagi Anggota Keluarga Inti (Nuclear Family) seperti yang sudah dijelaskan sebelumnya bahwa ruang privat merupakan sebuah wilayah yang aksesibilitasnya ditentukan oleh seseorang atau sekelompok orang dengan tanggung jawab ada pada mereka. Orang lain yang tidak memiliki hak atas ruangan tersebut tidak mudah untuk bisa memasuki ruang tersebut, melainkan harus memperoleh izin dari pihak yang memiliki hak atas ruang tersebut. Selain kamar mandi, ruangan di rumah tidak layak huni yang juga masuk ke dalam kategori ruang privat adalah kamar tidur.

Berbeda dengan kamar mandi, ruang privat di sini tidak termasuk ke dalam kategori teritori sekunder melainkan masuk ke dalam kategori teritori primer. Teritori primer merupakan tempat-tempat yang sangat pribadi sifatnya dan hanya boleh dimasuki oleh orang-orang yang sudah sangat akrab atau yang sudah mendapat izin khusus. Teritori ini dimiliki oleh perseorangan atau sekelompok orang yang juga mengendalikan penggunaan teritori tersebut secara relatif tetap (Laurens, 2005: 126).

Kamar tidur di rumah ini dimiliki oleh sekelompok orang yang termasuk ke dalam keluarga inti. Setiap keluarga inti yang tinggal di rumah tidak layak huni ini memili 1 kamar tidur tersendiri, sehingga mereka memiliki teritori primer di ruang kamar tersebut. Hanya anggota dari keluarga inti yang memiliki akses untuk bisa memasuki dan berada di ruangan kamar tidur tersebut. Untuk anggota keluarga lain, yang tidak termasuk ke dalam keluarga inti tidak bisa mengakses ruangan ini dengan mudah melainkan harus seizin dari pemilik ruangan.

Begitu pula dengan tanggung jawab dan kendali di dalam ruangan ini berada di tangan keluarga inti yang memiliki ruangan tersebut. Kamar tidur yang merupakan teritori primer bagi keluarga inti I menunjukkan bahwa tanggung jawab akan ruangan ini, seperti kebersihan dan keamanan menjadi tanggung jawab pemiliknya yang merupakan anggota keluarga inti. Kendali dalam ruangan ini juga berada di tangan mereka berdua. Saat mereka tidak ingin diganggu, maka mereka bisa menutup akses masuk ke dalam ruangan ini dengan menutup pintu tangga menuju kamar mereka.

Hal di atas menunjukkan bahwa penggunaan ruangan sangat berkontribusi pada komunikasi. Saat pintu kamar tidur ditutup oleh pemiliknya, petunjuk proksemik tersebut mengkomunikasikan bahwa pemilik ruang tersebut tidak ingin diganggu oleh penghuni rumah lainnya. Tanpa perlu untuk berkomunikasi secara verbal, anggota keluarga 
lain mengerti bahwa pemilik kamar tidak ingin diganggu. Kesepemahaman terjadi di situ. Tanpa ada komunikasi verbal, persamaan makna dapat terbentuk di antara sesama anggota keluarga tersebut.

Konsep privasi perlu diangkat untuk mengkaji aspek ini. Privasi merupakan keinginan atau kecenderungan pada diri seseorang atau kelompok untuk tidak diganggu kesendiriannya (Laurens, 2005: 157) .Tidak diganggu kesendiriannya di sini berarti tidak diganggu oleh anggota keluarga inti lainnya yang tidak diharapkan oleh diri orang tersebut. Dalamkonsep privasi, tidak berarti seorang diri. Seperti yang diungkapkan oleh Westin (1967) bahwa kadang-kadang seseorang juga ingin berada dalam kesendirian bersama seseorang atau beberapa orang yang dipilih olehnya. Seperti seseorang yang mendambakan berada di tempat khusus yang menjadi favoritnya bersama dengan seseorang yang dikasihinya (Dalam Laurens, 2005: 158).

Kamar tidur, sebagai sebuah teritori primer memberikan akses kepada para pemiliknya untuk bisa melakukan hal-hal yang bersifat pribadi. Ruangan kamar yang terdapat di rumah tidak layak huni bukan merupakan ruang yang dimiliki oleh satu orang, hal-hal bersifat pribadi di sini berarti bukan pribadi sebagai seorang diri, tetapi sebagai seorang anggota kelompok yang memiliki ruangan ini. Kamar tidur bukan hanya sebagai tempat tidur, tetapi kamar tidur adalah tempat di mana setiap anggota nuclear family yang memiliki kekuasaan di ruangan tersebut dapat saling berinteraksi dan berkomunikasi mengenai masalah-masalah mengenai anggota keluarga tersebut.

Sepasang suami istri yang ingin mendapatkan privasi di ruang kamar tidur saat mereka berhubungan suami istri, merupakan contoh dari penggunaan private space for nuclear family. Sebuah konsep ruang akan memiliki makna yang berbeda saat interaksi yang terjadi di dalamnya juga berbeda. Pada saat ruang kamar tidur ini digunakan secara bersama-sama oleh pasangan suami istri dan juga anaknya, yaitu ketika menonton televisi misalnya, menjadikan ruang kamar ini masuk ke dalam kategori public space for nuclear family, tapi saat ruangan ini digunakan oleh sepasang suami istri ketika berhubungan intim maka ruang kamar tidur ini masuk ke dalam kategori private space for nuclear family.

Konsep pribadi juga bergantung kepada akses pada privasi itu sendiri. Menurut Altman (dalam Laurens, 2005: 158), akses mendapatkan sebuah privasi dapat diperoleh melalui berbagai jalan. Sebagai sebuah contoh yang diungkapkan oleh Laurens, dalam banyak percakapan seseorang biasanya membiarkan lawan bicara untuk mempunyai akses kepadanya secara visual maupun akustikal. Artinya, lawan bicara tersebut bebas untuk melihat dan mendengarkannya, tetapi sama sekali tidak ada akses bagi lawan bicara tersebut untuk menyentuhnya. Itu merupakan wujud privasi seseorang saat melakukan sebuah percakapan. Hal ini menunjukkan betapa kompleksnya pengertian tentang privasi, dimana pada saat beberapa jalur komunikasi dapat terbuka sementara jalur lainnya tertutup.

Ketika pasangan suami istri ini berhubungan intim, anak dari pasangan suami istri tersebut berada dalam ruangan yang sama dengan mereka, yang dapat diartikan bahwa anak ini memiliki akses untuk dapat berada di ruangan yang sama dengan orang tuanya. Saat orang tuanya berhubungan seksual, dia tidak memiliki akses untuk dapat mendengar, melihat maupun mengganggu. Privasi menunjukkan adanya kontrol selektif, tidak serba otomatis, dan privasi tidak berarti menutup semua jalur, tetapi mampu mengontrol terbuka dan tertupnya jalur tersebut (Laurens, 2005: 158).

Pasangan suami istri dapat melakukan kontrol selektif pada anaknya yang berada pada ruangan yang sama untuk dapat memperoleh privasinya. Selain itu, privasi yang dirasakan oleh pasangan suami istri ini tidak serba otomatis, tapi melalui sebuah perencanaan yang mereka rasa itu sudah cukup untuk memperoleh privasinya di ruangan tersebut. Penelitian ini menunjukkan bahwa dalam sebuah ruangan yang sama, walaupun ruangan itu sempit, tetapi bisa memiliki fungsi yang berbeda, pada waktuwaktu yang berbeda pula.

Ruang Publik bagi seluruh keluarga inti (Public space for nuclear family) merupakan sebuah ruangan umum yang hanya diperuntukkan bagi keluarga inti (nuclear family). Rumah tidak layak huni ini ditinggali 
oleh sebuah keluarga besar (extended family) yang terdiri dari tiga keluarga (nuclear family). Kondisi keluarga yang seperti ini berkontribusi pada perilaku spasial yang terjadi di setiap ruangan. Public space for nuclear family ini merupakan sebuah ruangan milik nuclear family yang ada di rumah tidak layak huni dan bisa secara bebas diakses oleh seluruh anggota nuclear family tersebut.

Nuclear family yang merupakan sebuah keluarga yang hanya terdiri dari seorang ayah, ibu dan anak-anaknya yang belum dewasa atau belum kawin, memiliki sebuah ruang yang hanya digunakan oleh anggota keluarganya. Ruangan ini merupakan teritori primer bagi nuclear family tersebut di rumah tidak layak huni ini. Hal tersebut dimaksudkan, hanya anggota dari nuclear family tertentu yang dapat menggunakan ruangan ini, sedangkan angota nuclear yang lain tidak bisa dengan bebas menggunakan ruangan ini, melainkan harus berdasarkan izin dari pemilik ruangan ini.

Kamar tidur ini selain dapat masuk ke dalam kategori ruangn private space for nuclear family juga bisa masuk ke dalam kategori public space for nuclear family. Hal tersebut dikarenakan ruang tidur di rumah tidak layak huni digunakan oleh seluruh anggota dari nuclear family. Keluarga yang masih memiliki anak yang belum dewasa atau menikah, menggunakan ruangan kamar tidurnya sebagai ruang bersama.

Kamar tidur masuk ke dalam kategori public space for nuclear family saat digunakan bersama oleh seluruh anggota nuclear family. Perilaku spasial yang terjadi dalam kamar tidur saat masuk ke dalam kategori ini adalah perilaku yang bersifat umum, tidak personal, seperti perilaku saat menonton televisi bersama di ruangan ini. Maka dari itu, komunikasi yang terjadi di antara sesama anggota keluarga tersebut berisikan pesan-pesan yang bersifat umum.

Saat menonton televisi, merupakan perilaku yang menandakan bahwa ruangan ini akan menjadi daerah umum untuk anggota nuclear family, tetapi privat bagi anggota keluarga yang lainnya. Privat atau umum ini dimaksudkan dari interaksi yang terjadi dari setiap anggota nuclear family yang sama-sama sedang menonton televisi pada public space for nuclear family. Selain perilaku menonton televisi yang menjadi patokan bahwa ini merupakan hal yang bersifat umum, juga dari pesan-pesan yang disampaikan saat mereka berkomunikasi.Pesan-pesan yang disampaikan saat interaksi ini merupakan pesan-pesan yang bersifat umum bagi nuclear family tersebut, tetapi bersifat privat bagi anggota keluarga lainnya. Jadi bila dilihat secara luas, dalam konteks extended family, pesan yang disampaikan dalam ruangan ini merupakan pesan yang bersifat pribadi, karena hanya bisa diketahui oleh orang-orang yang masuk ke dalam nuclear family tertentu, tetapi bagi anggota nuclear family itu sendiri pesan tersebut merupakan pesan yang bersifat umum. Beberapa pesan yang disampaikan saat para anggota nuclear family ini saling berinteraksi dalam ruang kamar tidur ini didominasi oleh pesan-pesan mengenai masalah keuangan keluarga mereka.

Selain dilihat dari perilaku spasial dan pesan-pesan yang disampaikan saat anggota nuclear family saling berinteraksi, ciri dari ruangan yang masuk ke dalam kategori public space for nuclear family ini juga dapat dilihat dari aspek tanggung jawabnya. Dengan mengutip kembali apa yang disampaikan Laurens (2005: 139) mengenai ruang publik, bahwa tanggung jawab yang terjadi di dalam ruangan ini adalah tanggung jawab kolektif. Dalam konteks ruangan yang masuk ke dalam kategori public space for nuclear family ini, tanggung jawab ruangan berada di tangan semua anggota keluarga nuclear family yang tinggal di dalamnya.

Ruang tengah dan dapur merupakan dua ruang publik bagi seluruh anggota keluarga (Extended Family) di Rumah Tidak Layak Huni. Dua ruangan dalam rumah ini terbuka untuk umum baik untuk seluruh anggota keluarga yang tingal di rumah tidak layak huni maupun bagi orang lain di luar keluarga besar tersebut. Karena dalam konteks penelitian ini hanya dibahas mengenai teritori rumah (home territory) maka yang dimaksud publik di sini adalah wilayah umum yang bisa dimasuki oleh seluruh penghuni rumah saja, tidak termasuk bagi orang-orang di luar anggota keluarga yang tinggal di rumah yang tidak layak huni ini.

Posisi dapur dan ruang tengah yang berada di bagian depan rumah ini menjadi salah satu penyebab utama ruangan ini masuk ke dalam kategori teritori publik. Ruangan yang sekarang 
digunakan sebagai dapur, seharusnya adalah sebuah teras yang berada di depan rumah. Tetapi karena sempitnya luas tanah yang dimiliki, maka teras ini pun akhirnya berubah fungsi menjadi sebuah dapur. Peralihan fungsi dari teras menjadi dapur menyebabkan perilaku spasial yang terjadi di ruangan ini menjadi berbeda. Semua anggota keluarga dapat menggunakan ruangan ini walaupun mereka tidak menggunakannya untuk memasak atau sesuai dengan fungsi sebuah dapur. Mayoritas dari penghuni rumah menggunakan dapur hanya sebagai akses keluar masuk rumah yang tidak layak huni ini.

Hal serupa juga terjadi di ruang tengah. Ruangan yang berada tepat setelah posisi dapur merupakan akses jalan yang harus digunakan oleh seluruh anggota keluarga apabila mereka ingin memasuki ruangan lainnya di rumah ini, seperti kamar mandi dan kamar tidurnya. Kondisi ini yang menyebabkan ruang tengah masuk ke dalam kategori publik yang dapat diakses oleh seluruh penghuni tanpa harus meminta izin terlebih dahulu.Perilaku spasial yang terjadi di ruangan ini adalah perilaku yang bersifat umum. Tidak terungkapkan sedikit pun kegiatan privat yang terjadi di dalam ruangan ini.

Kedua ruang di atas dapat disebut sebagai public space for extended family yaitu sebuah ruangan di dalam rumah yang bisa dimasuki dan digunakan oleh seluruh penghuni rumah yang tinggal di rumah tidak layak huni. Ruangan ini merupakan sebuah teritori publik yang bisa dipergunakan oleh seluruh anggota keluarga.Perilaku spasial yang terjadi di ruangan ini bisa berupa perilaku yang bersifat umum.

Ruang tengah merupakan sentral bagi kegiatan seluruh anggota keluarga yang bersifat umum. Ruangan ini menjadi pusat kegiatan keluarga karena ruangan ini merupakan ruangan yang paling strategis. Selain itu, ruang tengah merupakan ruangan yang memiliki ukuran paling besar bila dibandingkan dengan ruangan lain di rumah yang itdak layak huni. Kestrategisan dan ukuran yang bisa dibilang luas untuk kategori rumah tidak layak huni ini, menjadi alasan utama mengapa ruangan ini menjadi ruangan yang termasuk pada teritori publik.

Seperti yang diungkapkan Laurens (2005: 139) bahwa ruang publik merupakan area yang terbuka. Ruang ini dapat dicapai oleh siapa saja pada waktu kapan saja dan tanggung jawab pemeliharaannya adalah kolektif.Seperti yang sudah dijelaskan bahwa ruangan ini digunakan oleh seluruh anggota keluarga pada waktu yang tidak ada ditentukan. Saat salah satu anggota rumah yang ingin menyelesaikan pekerjaannya di ruangan ini, tidak perlu meminta izin kepada siapa pun yang berada di rumah ini.

Begitu pula dengan masalah tanggung jawab. Tidak ada yang memiliki tanggung jawab khusus baik untuk ruang tengah maupun dapur. Semua penghuni rumah bertanggung jawab atas kedua ruangan ini. Saat mengerjakan suatu pekerjaan di ruang tengah maupun dapur maka dialah yang bertanggung jawab atas ruangan tersebut.

Daripemaparan diatas, berikutmerupakan sebuah model yang dapat menggambarkan mengenai konsepsi ruang yang terdapat di rumah tidak layak huni.

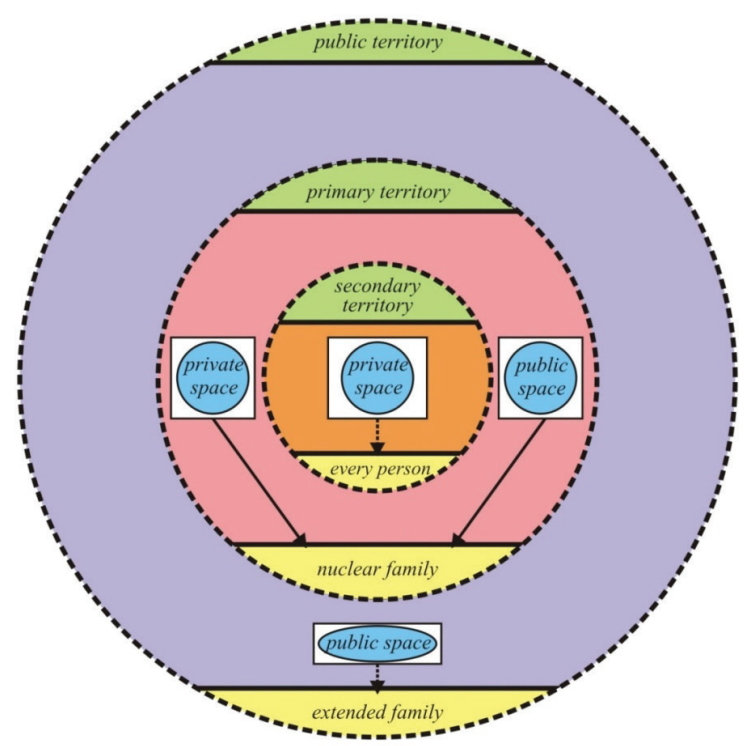

Gambar 2. Konsepsi Ruang di Rumah Tidak Layak Huni

Model konsepsi ruang di atas menunjukkan pembagian ruang yang terjadi di rumah tidak layak huni. Proksemik merupakan sebuah kajian yang berhubungan dengan ruang antarpeserta komunikasi (Liliweri, 1994: 116), jadi model di atas dapat dilihat sebagai sebuah model proksemik yang terjadi di dalam sebuah rumah yang tidak layak huni yang diperolah dari penelitian ini.

Ruang di dalam sebuah rumah yang tidak layak huni memiliki ukuran yang sangat kecil dan tidak layak. Fixed featured space atau bentuk komunikasi nonverbal dalam 
pemanfaatan ruang yang terdiri unsur-unsur fisik tertentu yang bersifat permanen atau tidak dapat dipindahkan di dalam rumah tidak layak huni ini hanya berukuran tidak lebih dari 2,5 m x $2 \mathrm{~m}$ untuk setiap ruangnya. Dalam ukuran rumah yang maksimal sebesar itu membuat jarak komunikasi yang terbentuk pun menjadi sangat kecil. Padahal menurut Galvin dan Brommel dalam bukunya Family Communication (1982: 251), menyatakan bahwa kondisi dari sebuah ruang akan berkontribusi kepada komunikasi yang terjadi di antara para penghuni ruang tersebut. Dalam model tersebut digambarkan tiga buah lingkaran yang dibuat dalam garis terputurputus. Garis terputus-putus menggambarkan bahwa penghuni di dalam rumah bisa menjadi sebuah bagian dari sebuah keluarga besar (extended family), keluarga inti (nuclear family), dan dirinya sendiri sebagai seorang individu yang memiliki hal-hal pribadi yang tidak ingin diketahui oleh orang lain. Hal tersebut berimplikasi ke dalam pembagian ruang yang ada di dalam rumah tersebut.

Ruang yang hanya bisa digunakan oleh setiap penghuni rumah sebagai seorang individu yang independen hanyalah ruang yang difungsikan sebagai kamar mandi. Dalam ruangan ini, setiap penghuni rumah memiliki privasinya secara penuh. Hal tersebut ditunjukkan dengan interior ruangan tersebut yang dilengkapi oleh sebuah pintu yang memiliki kunci. Oleh karena itu, ruangan kamar mandi ini diklasifikasikan ke dalam private space for everyperson atau ruangan yang privat untuk setiap penghuni rumah tidak layak huni.

Kamar mandi yang merupakan sebuah ruangan milik bersama tetapi dipakai secara bergantian dengan anggota keluarga yang lain, menjadikan kamar mandi ini sebagai sebuah wilayah sekunder dalam rumah yang tidak layak huni. Seperti yang disampaikan Laurens (2005: 127) bahwa teritori sekunder merupakan tempat-tempat yang dimiliki bersama oleh sejumlah orang yang sudah cukup saling mengenal. Kendali pada teritori ini tidaklah sepenting teritori primer dan kadang berganti pemakai atau berbagi penggunaan dengan orang asing.

Di dalam ruangan ini memang penggunanya mendapatkan privasi yang penuh, tetapi privasi tersebut hanya sebatas privasi visual. Ketika berada dalam ruangan ini, pengguna ruangan memiliki kebebasan untuk mengekspresikan dirinya secara visual, seperti mandi yang sudah pasti dilakukan tanpa menggunakan pakaian. Hal ini dapat dilakukan karena privasi yang diperoleh adalah privasi visual. Dengan adanya pintu yang menutupi ruangan ini secara penuh serta dilengakapi dengan sebuah kunci dari dalam membuat orang lain yang tidak mengunakan ruangan ini tidak memiliki akses untuk melihat apa yang dilakukan oleh pengguna ruangan tersebut.

Kondisi ruangan seperti ini tidak memberikan privasi secara audio atau akustikal. Pengguna kamar mandi tidak bisa mengekspresikan dirinya melalui sebuah kata-kata verbal di dalam ruangan ini karena akan terdengar ke luar ruangan. Hal tersebut menunjukkan bahwa saat berada di dalam kamar mandi, pengguna kamar mandi yaitu seluruh penghuni rumah tidak layak huni tidak bisa mengungkapkan kata-kata verbal yang sifatnya personal atau rahasia karena akan terdengar oleh penghuni rumah lain yang ada di luar ruangan. Kata-kata verbal yang disampaikan dalam ruangan ini hanya sebatas nyanyian atau pesan-pesan umum yang memang boleh atau memang ditujukan kepada penghuni rumah lain yang ada di luar ruangan tersebut. Pesan yang bersifat umum ini berisikan permintaan tolong dan disampaikan secara langsung dengan volume suara yang sedikit dinaikkan, untuk menyaingi suara air yang ada di kamar mandi serta untuk menembus batas pintu kayu.

Lingkaran yang kedua menggambarkan bahwa beberapa penghuni rumah yang tergabung dalam sebuah keluarga inti (nuclear family) memiliki ruangan yang berbeda satu sama lain. Setiap keluarga inti (nuclear family) memiliki ruangan yang khusus menjadi hak miliknya. Ruangan yang menjadi hak milik keluarga inti ini merupakan sebuah ruangan yang masuk ke dalam ketegori primer atau sebuah tempat yang sangat pribadi sifatnya dan hanya boleh dimasuki oleh orang-orang yang sudah sangat akrab atau yang sudah mendapat izin khusus. Teritori ini dimiliki oleh perseorangan atau sekelompok orang yang juga mengendalikan penggunaan teritori tersebut secara relatif tetap (Laurens, 2005: 126). Setiap 
anggota keluarga memiliki kewenangan untuk melarang atau mengizinkan orang lain di luar keluarga intinya untuk masuk ke ruangan ini.

Ruang yang termasuk ke dalam kategori primer ini adalah ruang kamar tidur. Kamar tidur yang seharusnya merupakan milik dari setiapindividupenghunirumahatau pasangan suami istri, tetapi karena keterbatasan ruang mengakibatkan kamar tidur digunakan oleh seluruh anggota keluarga inti. Penggunaan kamar tidur secara bersamaan membentuk sebuah konsep ruang yang berbeda, karena ruangan ini dapat berfungsi sebagai ruang privat maupun ruang publik. Pengalihan fungsi ruangan dipengaruhi oleh konsep waktu penggunaan kamar.

Kamar tidur sebagai sebuah ruang publik terjadi ketika seluruh anggota keluarga inti berada dalam ruangan tersebut dan tidak dalam kondisi tidur (public space for nuclear family). Pada saat salah satu anggota keluarga inti, yaitu anak sedang dalam kondisi tidur maka ruangan ini berubah menjadi sebuah ruang privat untuk pasangan suami istri tersebut (private space for nuclear family).

Konsep privat tidak bisa dilihat secara sederhana. Privasi adalah sebuah hal yang kompleks. Privasi melibatkan seluruh alat indera seseorang. Privat dalam artian disini hanya sebatas privat secara visual (sama dengan ruangan kamar mandi), karena keluarga yang lain yang berada di dalam ruangan ini dinyatakan tertidur dengan bukti matanya yang tertutup. Penelitian ini perlu untuk membuktikan lebih lanjut bahwa anggota keluarga tersebut dalam kondisi tertidur. Secara akustikal, privasi tidak terbentuk dalam ruangan ini. Ruangan kamar yang hanya dibatasi oleh triplek dengan ruangan lainnya serta tidak adanya sekat apapun yang membatasi tempat tidur orang tua dengan anak menjadikan privasi akustikal itu tidak terjadi di dalam ruangan ini. Ketika pasangan suami istri ini berhubungan suami istri, komunikasi personal lainnya tidak dapat disampaikan dengan bebas. Komunikasi hanya dilakukan dengan simbol-simbol nonverbal lain yang dalam penelitian ini tidak dibahas secara dalam.

Sesuai dengan apa yang disampaikan oleh Dra. Ema Sukaemah, Psi., sebagai triangular dalam penelitian ini, yang menyatakan bahwa dalam sebuah ruangan yang sama yang ditempati oleh beberapa orang akan berakibat pada prviasi yang terbentuk di antara penghuni ruang tersebut. Berkali-kali psikolog keluarga ini menekankan bahwa ruang sangat berpengaruh pada komunikasi yang terjadi di dalam ruang tersebut. Keberadaan ruang akan memberikan pengaruh psikologis terhadap orang-orang yang berada di dalamnya. Pengaruh psikologis itulah yang berkontribusi pada komunikasi yang terbentuk di antara penghuni ruang.

Masih berdasar pada hasil wawancara dengan Dra. Ema Sukaemah, Psi., dalam sebuah kamar yang ditempati oleh pasangan suami istri dan anaknya yang sudah gadis, privasi yang terbentuk di dalam ruangan itu haruslah dikaji dengan lebih dalam lagi. Hal tersebut dikarenakan privasi merupakan suatu hal yang kompleks yang berkenaan dengan pancaindera manusia. Tetapi secara umum, melihat hasil penelitian ini, Dra. Ema Sukaemah Psi. menyatakan bahwa, mungkin orang tua memang menganggap ruangan itu sudah privat untuk mereka berhubungan suami istri hanya berdasar pada bukti bahwa anak gadisnya sudah tertidur lelap. Padahal itu belum tentu, karena privasi itu bukan hanya dari penglihatan tetapi juga dari suara. Pengaruh latar belakang pendidikan dan agama juga berkontribusi pada pemahaman mengenai konsep privasi dari penghuni ruang tersebut. Melihat latar belakang pendidikan yang memang rendah, memungkinan bagi mereka untuk menyatakan bahwa ruangan tersebut sudah privat.

Penelitian ini memang menunjukkan bahwa para orang tua yang tinggal di rumah tidak layak huni ini menganggap ruangan tempatnya berhubungan intim sudah merupakan ruangan pribadi, tetapi itu hanya konsep yang mereka yakini. Apabila kembali lagi pada sebuah konsep ruang privat/ private space adalah sebuah ruang yang hanya dimiliki oleh orang atau kelompok orang tertentu dengan kebebasan penggunaan ruangan tersebut, maka konsep ruang privat di rumah ini memang berkarateristik khusus, yaitu hanya privat untuk hal-hal yang bersifat visual dan kinestetik tetapi tidak secara akustikal.

Keterbatasan privasi dalam ruang privat ini menyebabkan pesan-pesan komunikasi yang disampaikan hanyalah pesan-pesan yang bersifat umum. Untuk pesan-pesan 
tersebut. Kondisi rumah yang sempit dan sekat pembatas di antara ruangan yang tidak permanen membuat privasi yang terbentuk dalam rumah ini hanyalah privasi yang berisfat visual tetapi tidak bersifat akustikal. Jadi walaupun jarak fisik yang terbentuk di rumah ini termasuk pada jarak personal, tetapi pesanpesan yang disampaikan dalam komunikasi antar sesama anggota keluarga adalah pesanpesan yang bersifat umum seperti pesan mengenai permasalahan rumah tangga, acara atau event yang sedang atau akan diikuti, aktivitas sehari-hari, gosip, serta humor.

Penelitian ini menemukan beberapa temuan yang menarik untuk dikaji lebih dalam. Salah satu temuan yang paling menarik adalah dimana seluruh penghuni rumah, tidak pernah mengkomunikasikan pesan-pesan yang bersifat personal atau rahasia di dalam rumah. Maka akan sangat menarik apabila melakukan studi etnografi komunikasi mengenai simbolsimbol komunikasi yang terdapat di rumah yang tidak layak huni.

Selain itu, peneliti menyarankan agar Dinas Tata Ruang dan Cipta Karya (Distarcip) Kota Bandung segera membenahi kondisi pemukiman kumuh tingkat satu ini. Hal tersebut dikarenakan kondisi pemukiman yang buruk berkontribusi kepada interaksi yang terjadi di masyarakatnya. Penyimpangan dalam segala aspek masih banyak terjadi di wilayah ini. Oleh karena itu akan lebih baik apabila dilakukan berbagai penyuluha, seperti mengenai masalah perilaku sehat di dalam rumah, cara mendidik anak dengan baik, sampai pada masalahmasalah sosial lainnya, seperti pendidikan seks untuk para remaja, penyadartahuan mengenai masalah Nafza, dan sebagainya.

\section{DAFTAR PUSTAKA}

Asy'ari, S. I. (1993). Sosiologi kota dan desa. Surabaya: Usaha Nasional

Burgess, E. W. \& Locke, H. J. (1960). The family form institution to companionship $2^{\text {nd }}$ edition. New York: American Book Company.

Creswell, J. W. (1998). Qualitative inquairy and reseach design. California: Sage Publications
Galvin, K. M. \& Brommel, B. J. (1982). Family communication cohesion and change. New York: scott Foresman and Company.

Guharja, S. (1992). Pengembangan sumber daya keluarga: bahan pengajaran. Bogor: BPK Gunung Mulia.

Hindarto, P. (2009). Diskusi tentang ruang dalam ruang angan arsitektur. Diakses melalui http://probohindarto.wordpress. com/2009/08/27/diskusi-tentangruang-dalam-ruang-angan-arsitek/.

Khairuddin. (2008). Sosiologi keluarga. Yogyakarta: Liberty.

Laurens, J. M. (2005). Arsitektur dan perilaku manusia. Jakarta: Grasindo.

Liliweri, A. (1994). Perspektif teoritis, komunikasi antar pribadi (suatu pendekatan ke arah psikologi sosial komunikasi). Bandung: Citra Aditya Bakti.

(1994). Komunikasi verbal dan non verbal. Bandung: Citra Aditya Bakti

Mulyana, D. (2002). Metode penelitian komunikasi. Bandung: Remaja Rosdakarya.

..............(2002). Ilmu komunikasi suatu pengantar. Bandung: Remaja Rosdakarya.

Nazir, M. (2003). Metode penelitian. Jakarta: Ghalia Indonesia.

Rakhmat, J. (2003). Psikologi komunikasi. edisi Revisi. Bandung: Remaja Rosdakarya.

Riyantie, M. (2013). Implementasi CSR Melalui Program "Kampoeng BNI" oleh PT BNI (PERSERO) TBK. Jurnal Kajian Komunikasi. Volume 1 Nomor 2 Tahun 2013.

Salim, A. (2001). Teori dan paradigma penelitian sosial (dari Denzin Guba dan penerapannya). Yogyakarta: Tiara Wacana Yogya.

Suparlan, S. (1993). Kemiskinan di perkotaan. Jakarta: Yayasan Obor. 
yang bersifat personal atau rahasia tidak disampaikan secara lisan tetapi melalui simbol-simbol nonverbal lainnya, yang tidak dibahas pada penelitian ini.

Konsepsi ruangan yang berikutnya adalah ruang publik yang digunakan oleh seluruh anggota keluarga yang tinggal di rumah tidak layak huni ini. Ruangan yang masuk ke dalam kategori ini adalah ruang tengah dan teras yang difungsikan sebagai sebuah dapur. Ruangan yang merupakan teritori publikinibebas diakses oleh seluruh penghuni rumah. Tanggung jawab di dalam ruangan ini merupakan tanggung jawab yang kolektif. Setiap penghuni rumah bebas memasuki ruangan ini dan melakukan apapun yang mereka inginkan, sehingga ruangan pun menjadi tanggung jawab seluruh penghuni rumah.

Penghuni rumah tidak akan mendapatkan privasi di dalam ruangan ini karena ruangan ini bebas diakses oleh seluruh penghuni rumah. Ruang publik ini merupakan akses bagi seluruh penghuni rumah untuk keluar ataupun masuk rumah tidak layak huni ini. Selain itu, kondisi pintu yang tidak berkunci menyebabkan privasi tidak akan terbentuk dalam ruangan ini. Kondisi seperti itu berimplikasi kepada komunikasi yang terjadi di dalam ruangan tersebut. Pesan-pesan yang disampaikan dalam ruangan ini hanyalah pesan-pesan komunikasi yang bersifat umum.

Selama dilakukannya penelitian ini, baik dari hasil observasi maupun wawancara tidak ditemukan petunjuk-petunjuk yang menggambarkan adanya komunikasi verbal yang bersifat personal. Kondisi ruangan rumah yang sempit, antarruang hanya dibatasi oleh selembar triplek, dan juga tidak adanya pintu yang dapat dikunci mengakibatkan setiap anggota keluarga tidak mengungkapkan hal-hal pribadinya secara verbal. Penelitian menunjukkan bahwa untuk hal-hal yang bersifat personal atau rahasia disampaikan melalui bentuk simbol-simbol nonverbal atau disampaikan di luar ruang rumah.

Konsep ruang yang dibentuk dalam rumah tidak layak huni ini ternyata berkontribusi pada perilaku komunikasi yang terjadi dalam setiap ruang. Dengan melihat dan menganalisis setiap bentuk ruang beserta atribut yang berada di dalamnya serta perilaku spasial yang terbentuk dalam setiap ruang tersebut menghasilkan sebuah konsepsi ruang khusus di rumah tidak layak huni ini.

Pembahasan mengenai konsepsi ruang juga memberikan gambaran mengenai privasi yang terbentuk. Privasi yang bersifat visual saja dan tidak adanya privasi akustikal, berkontribusi pada pesan-pesan yang disampaikan dalam peristiwa komunikasi di rumah ini. Penelitian ini menunjukkan bahwa pesan-pesan yang disampaikan dalam rumah ini hanyalah pesan-pesan yang bersifat umum seperti (1) masalah rumah tangga, seperti penagihan atau pembayaran uang listrik, air, tanah rumah, kemanan dan kebersihan, (2) perintah atau larangan untuk melakukan sesuatu hal, (3) acara/ event, (4) aktivitas anggota keluarga seperti keberadaan anggota keluarga yang lain, (5) kondisi fisik dari masing-masing anggota keluarga, (6) gosip seperti membicarakan permasalahan rumah tangga tetangga, selebritis, ataupun sinetron, (7) humor seperti saling mengolok-olok anggota keluarga yang lain.

\section{SIMPULAN}

Konsepsi ruang di rumah tidak layak huni, dibagi ke dalam empat kategori ruang yaitu (1) ruang privat untuk setiap penghuni (private space for everyperson), (2) ruang privat untuk keluarga kecil (private space for nuclear family), (3) ruang publik untuk keluarga kecil (public space for nuclear family), dan (4) ruang publik untuk keluarga besar (public space for extended family). Konsepsi ruang tersebut tidak hanya dilihat dari aspek pengguna ruangan itu saja tetapi juga dari kategori wilayah yang terbentuk dalam rumah tidak layak huni ini. Ruang privat untuk setiap penghuni rumah atau private space for everyperson merupakan ruang yang masuk ke dalam teritori sekunder. Ruang privat untuk keluarga inti atau private space for nuclear family dan ruang publik untuk keluarga kecil atau public space for nuclear family merupakan konsepsi ruang yang masuk ke dalam kategori primer. Ruang publik untuk keluarga besar atau public space for extended family merupakan ruangan yang masuk ke dalam kategori teritori publik.

Ruang di dalam rumah tidak layak huni merupakan sebuah pesan nonverbal proksemik dalam segala aktivitas komunikasi yang dilakukan para penghuni di dalam rumah 
Suptandar, J. P. (1999). Desain interior: pengantar merencana interior. untuk mahasiswa desain dan arsitektur. Jakarta: Djambatan.
Trenholm, S. \& Jensen, A. (2004). Interpersonal communication theory $5^{\text {th }}$. NewYork: Oxford University Press. 